\title{
Preventing ischial pressure ulcers: I. Review of neuromuscular electrical stimulation
}

\author{
Hilton M. Kaplan* and Gerald E. Loeb \\ Department of Biomedical Engineering and Alfred Mann Institute for Biomedical Engineering, \\ University of Southern California, Los Angeles, CA, USA
}

\begin{abstract}
Objective: Pressure ulcers (PUs) are common and debilitating wounds that arise when immobilized patients cannot shift their weight. Treatment is expensive and recurrence rates are high. Pathophysiological mechanisms include reduced bulk and perfusion of chronically atrophic muscles as well as prolonged occlusion of blood flow to soft tissues from lack of voluntary postural shifting of body weight. This has suggested that PUs might be prevented by reanimating the paralyzed muscles using neuromuscular electrical stimulation (NMES). A review of the published literature over the past 2 decades is detailed.

Outcomes: Historically gluteus maximus (GM) has been an important target for NMES, but results have been difficult to interpret and suitable technology has been lacking.

Conclusions: NMES of the buttock muscles appears to be valuable in terms of its trophic effects, improving vascularity and soft tissue bulk. It remains unclear, however, whether GM can actually achieve sufficient unloading of normal forces to permit blood flow in the capillary beds of the skin and muscle. Analysis of the skeletal biomechanics is required to assess the relative value of GM vs. hamstring (HS) hip extensors in this regard.
\end{abstract}

Keywords: Decubitus ulcer, neuromuscular electrical stimulation, pressure ulcer prevention, gluteus maximus, hamstrings, spinal cord injury

Abbreviations

$\begin{array}{ll}\text { DTI } & \text { Deep Tissue Injury } \\ \text { FES } & \text { Functional Electrical Stimulation } \\ \text { FMS } & \text { Functional Magnetic Stimulation } \\ \text { GM } & \text { Gluteus Maximus } \\ \text { HS } & \text { Hamstrings } \\ \text { IT } & \text { Ischial Tuberosity } \\ \text { NMES } & \text { Neuromuscular Electrical Stimulation } \\ \text { PU } & \text { Pressure Ulcer } \\ \text { SARS } & \text { Sacral Anterior Root Stimulator } \\ \text { SCI } & \text { Spinal Cord Injury }\end{array}$

${ }^{*}$ Corresponding author: Hilton M. Kaplan, MD, PhD, PO Box 2337, Beverly Hills, CA 90213, USA. Tel.: +1 (310) 570 2822, Fax: +1 (310) 274 9931; E-mail: hkaplan@alumni.usc.edu.

\section{Introduction}

This is the first of three papers regarding the potential for chronic neuromuscular electrical stimulation (NMES) to prevent ischial pressure ulcers in paraplegic patients. This paper reviews the clinical problem and previous attempts to use NMES for this purpose. The two companion papers: 1) describe the musculoskeletal biomechanics, and 2) report on a pilot clinical study of a new technology that enables a recommended treatment strategy.

\section{Clinical scope and outcomes}

Pressure ulcers (PUs) are a debilitating pathology that can result in severe morbidity (e.g. sepsis, osteomyelitis, renal failure, cardiac failure) [70]. Approx- 
imately $30 \%$ of immobile patients develop PUs [54]. The buttocks is by far the commonest region affected, accounting for over $70 \%$ of all PUs (46\% sacral; $26 \%$ ischial) [39]. Groups particularly at risk are patients with spinal cord injury (SCI) and the elderly who have lost mobility from stroke, dementia, frailty, Parkinson's disease, etc. The prevalence of SCI in the US was $\sim 262,000(231,000-311,000)$ in 2009, with an incidence of $\sim 12,000$ new injuries per year ( 40 per million US) [57]. The incidence of PUs in SCI is $~ 33.5 \%$ during initial rehabilitation, and up to an additional $30 \%$ in the 30 years post-injury [56]; along with a similar prevalence [23]. In SCI $\sim 45 \%$ of these are ischial/sacral, with $11.3 \%$ at Stage III/IV (III = full thickness tissue loss; IV = exposed bone, tendon or muscle) [56].

Many preventive and therapeutic modalities are employed, but to little avail. For prevention, the current mainstay is load reduction, through regular weightshifting together with passive cushions and varieties of pneumatic devices over the years $[2,63]$. Immobile patients must change position every 2 hours when recumbent and every 15-20 min when seated [71]. This high demand results in poor compliance, especially in patients who do not feel pain or discomfort, or are ineffective at independently shifting their weight [28]. For treatment, the conservative mainstay is prolonged passive load reduction and medical support. Aggressive surgical repair is required, however, in as many as $\sim 70 \%$ of Stage III/IV PUs [12]. Flap reconstruction to provide well-vascularized, bulky tissue to cover bony prominences was pioneered by Davis in the 1930s [18]. Since 1970, gluteal flaps have been used widely, as originally described by Ger $[21,50]$. Although still the best option available, post-operative recurrence rates are as high as $61 \%$ within the first year of repair, and vary widely $[19,65]$ (Table 1$)$. The literature, although fragmentary, confirms that patients frequently resume sitting on their repaired sites, thus reinitiating all of the etiological mechanisms. Furthermore, the flap tissues in SCI are not as healthy, thick, vascularized or resistant to PUs as in non-SCI subjects.

The high recurrence rates compound costs of $\$ 50-80 \mathrm{~K}$ per incident. Furthermore, hospital stays increase 3-5 fold vs. age- and pathology-matched nonPU patients. The cost of treating all PUs in the US has been estimated to exceed \$56B annually (average increased hospital stay of 21.6 days at $\$ 2,360$ per day, in almost 1.1 million patients per year) [53].

\section{Pathophysiology}

Pressure ulcers are associated with both pressure and shear in soft tissues [75]. In addition to the capillary occlusion that results from both of these factors $[25,45,68]$ many other etiological mechanisms contribute too, including lymphatic occlusion, reperfusion injury, and tissue deformation [1, 3, 26, 64]. Finite element modeling of the latter, predicts that as dead cells accumulate, the resultant microstructural heterogeneity further deforms surviving cells, thereby aggravating

Table 1

Recurrence rates after surgical flap repairs for PUs over past 2 decades (sampling of papers)

\begin{tabular}{|c|c|c|c|}
\hline Year & Group & $n$ & Recurrence rates \\
\hline 1992 & Disa, 1992 & 66 flaps & $\begin{array}{l}61 \% \text { PUs and } 69 \% \text { pts, at mean of } 9.3 \text { mo.s despite } \\
80 \% \text { healed at discharge }\end{array}$ \\
\hline 1994 & Evans, 1994 & 22 paraplegics & $82 \%$ surgical site, and $64 \%$ new sites \\
\hline 1997 & Foster, 1997 & $\begin{array}{l}139 \text { ischial PUs in } 114 \text { consecutive } \\
\text { pts over } 16 \text { yrs }\end{array}$ & $\begin{array}{l}17 \% \text { at mean of } 10.7 \text { mo.s prior flap reconstruction } \\
\text { had been performed in } 60 \%\end{array}$ \\
\hline 1998 & Kierney, 1998 & 268 PUs in 158 pts over 12 yrs & $\begin{array}{l}21 \% \text { ischial flaps at mean of } 3.7 \text { yrs } 23 \% \text { all flaps in } \\
\text { SCIs ( } 24 \% \text { paraplegics; } 20 \% \text { tetraplegics) }\end{array}$ \\
\hline 1999 & Tavakoli, 1999 & 23 pts & $\begin{array}{l}57 \% \text { paraplegics, } 33.3 \% \text { tetraplegics, at mean of } 62 \\
\text { mo.s paraplegics responsible for their own } \\
\text { weight-relief may be less fastidious than } \\
\text { tetraplegics who require caregivers? }\end{array}$ \\
\hline 2000 & Schryvers, 2000 & 191 ischial PUs over $20 \mathrm{yrs}$ & $34 \%$ at range of $2-36$ mo.s \\
\hline 2003 & Margara, 2003 & 121 ischial PUs over 15 yrs & $\begin{array}{l}33 \% \text { over first } 7 \text { yrs }(n=57) 9 \% \text { over next } 8 \text { yrs on } \\
\text { stricter treatment protocol }(n=64)\end{array}$ \\
\hline 2004 & Coşkunfirat, 2004 & $\begin{array}{l}35 \text { gluteal PUs in } 32 \text { consecutive pts } \\
\text { over } 4 \text { yrs }\end{array}$ & $3 \%$ at mean of 13.6 mo.s \\
\hline 2005 & Kuwahara, 2005 & 8 sacral PUs & $38 \%$ at 1 to 4 yrs \\
\hline 2009 & Keys, 2009 & 231 flaps in 139 pts over 15 yrs & $36 \%$ surgical site \\
\hline 2009 & Lee, 2009 & 20 ischial PUs over 8 yrs & $50 \%$ surgical site, at mean $74.2 \mathrm{mo}$. \\
\hline
\end{tabular}


the spread of tissue damage $[1,13,14]$. These mechanical changes then lead to increased stresses in the injured area, resulting in a "snowball effect" that is difficult to halt [1]. Pathologic changes are more severe in muscle than in skin or subcutaneous tissues [67, 73], perhaps reflecting the higher metabolic demands of muscle and explaining the importance and prevalence of deep tissue injury (DTI) $[25,66,67,73]$. PU severity is most commonly staged according to the National Pressure Ulcer Advisory Panel system, originally put forward in 1989 based on Shea's classical staging from 1975 [4, 62]. It consistently remained a 4-stage system (“Stages I-IV”), until 2007 when two additional stages were added: "Suspected Deep Tissue Injury" (DTI) and "Unstageable" [55]. The current staging system is represented in Fig. 1.

Current hypotheses about effective preventive measures generally fall into 3 broad categories: 1) weight-shifting to relieve and improve pressure distribution; 2) increasing muscle volume to provide more padding; and 3) increasing vascularity and perfusion to reduce hypoxia and accelerate recovery. These factors have reason to be correlated with each other, as well. For example, active use of a muscle immediately increases its metabolic demand and eventually increases its physical size; both factors stimulate development of its blood supply [36, 46, 58, 59]. In areas such as the buttocks where the overlying skin is supplied by musculocutaneous perforator vessels, that skin should also benefit from this improved blood supply.
Able-bodied people do not get PUs, presumably because they can voluntarily contract their muscles, thereby maintaining muscle bulk and vascularity, while shifting their weight to relieve seating pressure and so restore capillary circulation. While this should work successfully in the skin of the buttocks, it is less clear how this provides any relief in the gluteus maximus (GM) muscles when seated, where ischemic necrosis can give rise to deep ulcers independent of the overlying skin. Muscle activity increases metabolic demand while simultaneously generating hydrostatic pressure that tends to occlude intramuscular capillary beds, making it even more important not to occlude these vessels by external pressures and shear during such use.

Ever since the classic Reswick \& Rogers curve was published in 1976 [60], PU risk has been recognized as proportional to the product of pressure intensity and duration $[9,16,37,60]$. Soft tissues should therefore be able to handle higher pressures and metabolic demands when relieved by intermittent periods of low pressure during which circulation is reestablished. Able-bodied people do not get PUs, presumably because they can voluntarily contract their muscles, thereby maintaining muscle bulk and vascularity, while shifting their weight to relieve seating pressure and so restore capillary circulation. NMES could be used to activate paralyzed muscles to achieve the same beneficial effects, but the choice of target muscle(s) is not obvious. One candidate muscle is the gluteus maximus (GM), a hip

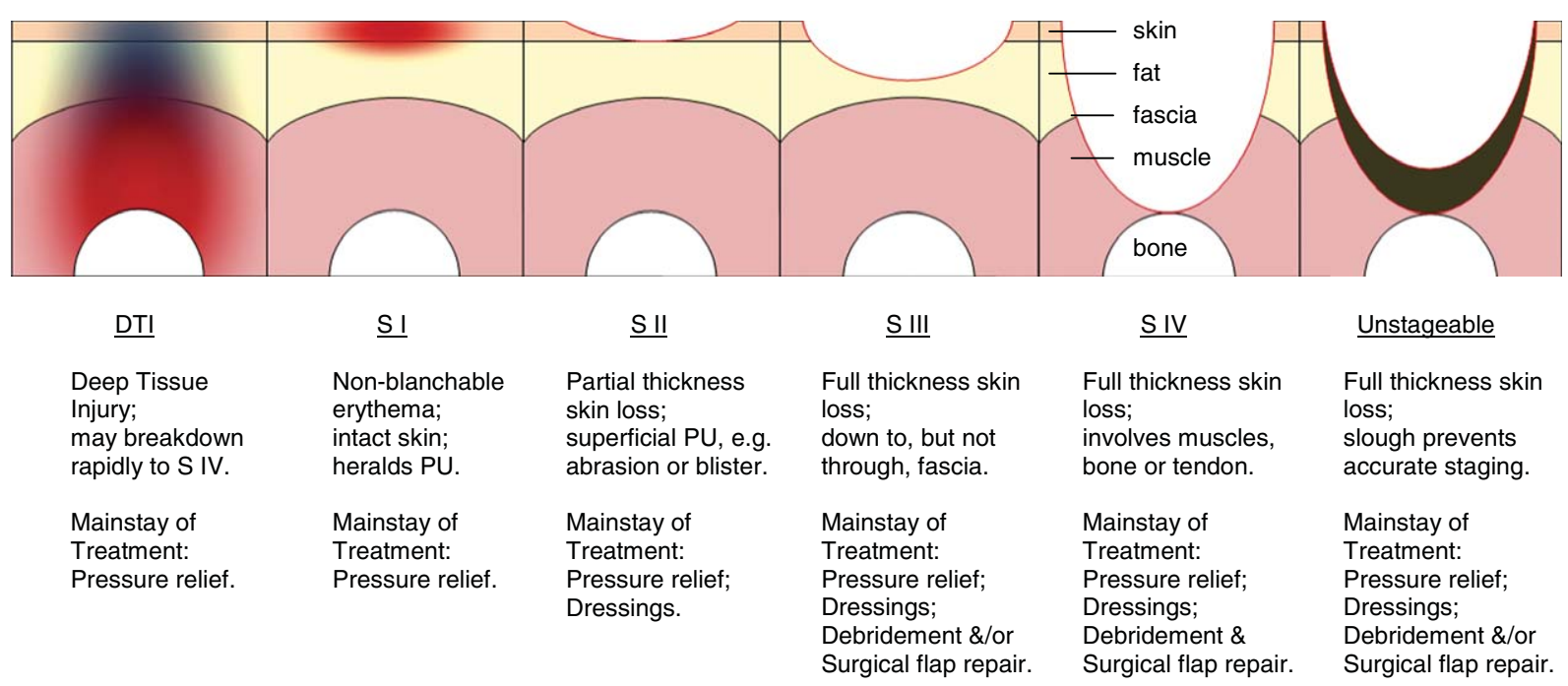

Fig. 1. Author's representation of the National Pressure Ulcer Advisory Panel (NPUAP) PU staging system (NPUAP 2007). 
extensor, but this muscle is itself at risk of ischemic necrosis in PU prevention. Muscle activity increases metabolic demand while simultaneously generating hydrostatic pressure that tends to occlude intramuscular capillary beds. One obvious problem with using the GM muscles to unload the ischium is that there would be little or no time for circulation to be reestablished. When the muscles are passive, the weight of the body results in intramuscular pressure that occludes blood flow. When the muscles are active, the contractile force is accompanied by an increase in hydrostatic pressure that also tends to occlude blood flow. Nevertheless, some benefits of GM activation have been described empirically, as discussed below.

\section{Experience with NMES}

\subsection{State of the art}

The seminal work by Levine et al. [42], in one SCI (C4) and four able-bodied individuals, demonstrated that seated interface pressures could be redistributed by NMES of GM. Importantly, they claimed redistributions rather than reductions of ischial seating pressures. This group also promoted the significance of gluteal blood flow and soft tissue volume for PU risk [41, 43, 44].

In 1992 Ferguson's group demonstrated in 9 SCI subjects that NMES of the quadriceps could produce actual reductions in seated interface pressures. They proposed that these reductions were more appropriate than the redistributions that had been shown by Levine's group with NMES of GM [21]. Their protocol involved a 3 months conditioning program (30 min/day $\times 5+$ days/week) prior to testing, and resulted in average ischial pressure reductions of $3.6 \mathrm{kPa}(27 \mathrm{mmHg})$ and $5.9 \mathrm{kPa}(44 \mathrm{mmHg})$ on the left \& right sides respectively (from means of $10.1 \mathrm{kPa}(76 \mathrm{mmHg}$ ) and $13.2 \mathrm{kPa}(99 \mathrm{mmHg})$ respectively at rest). Some minor modifications of the subjects' wheelchairs were required, together with restraint of their lower legs. This approach also does not provide the potential local (GM) circulatory and muscle hypertrophy benefits that Levine's technique does. Further, quadriceps is primarily an extensor of the knee, but not of the hip. One of the four heads, rectus femoris, actually flexes the pelvis on the femur [17, 52], rather than extending it as might be desirable for unloading without having to stabilize the trunk. Finally, imbalanced stresses on the knee joints could potentially cause damage if this technique were employed chronically. For these reasons we do not consider it the most preferable actuator for achieving all three mechanisms of action of NMES listed above (weight-shifting, increased seat muscle volume, and increased tissue health/vascularity).

More recently, other research groups have extended Levine's original case study by using different GM stimulation methodologies in larger numbers of SCI patients. Bogie, et al. [5] investigated the short-term effects of regular use of gluteal NMES in users of a semi-implanted system primarily for Functional Electrical Stimulation (FES) assisted standing and transfers. Early results reported that interface pressures in the ischial region could be significantly reduced through stimulating GM, with positive tissue health benefits ([5, 6]. In 2003 they reported on a conditioning exercise program improving tissue health in 8 patients using this same system over 8 weeks, through improved regional blood flow and interface pressure distributions [7]. Regular stimulation of GM was included as part of their exercise and standing routines. Statistically significant reductions in ischial interface pressures were reported at post-exercise assessments $(p<0.01)$, but the effect on ischial pressures during stimulation was not assessed. More recently this group appraised the long-term effects of isolated gluteal NMES for shifting weight and conditioning tissues in a single subject [8]. This case study reported the results of a 4-channel semi-implanted system used over 7 years. Absolute regions of statistically significant change in pressure were determined, but the quantitative and spatial extent of these "absolute differences" or "variations" were not provided (i.e. whether pressures actually went up or down, and by how much, in different zones during stimulation). Improvements in tissue health variables (gluteal thickness and transcutaneous $\mathrm{O}_{2}$ ) were noted, and the authors predicted that daily NMES would be required to prevent disuse atrophy from recurring.

In 2006 Liu's group reported on GM activation via stimulation of the S2 sacral roots [47, 48]. They compared Functional Magnetic Stimulation (FMS) in 5 able-bodied subjects with electrical stimulation via an implanted Sacral Anterior Root Stimulator (SARS) in 5 SCI subjects. The S2 nerve roots were demonstrated to reliably activate the gluteal muscles in both cases, but simultaneous direct or reflexive activation of the hamstring (HS) hip extensors cannot be ruled out. Average peak pressures were reported for only small $\left(1.3 \times 1.3=1.6 \mathrm{~cm}^{2}\right)$ regions directly under the ischial 
tuberosities (ITs), where they were found to be reduced by $20 \%$ with FMS and by $33 \%$ with SARS.

In 2007-2008 Janssen et al. reported on the benefits of GM activation through surface stimulation in 13 SCI males [30, 72]. Alternating side-toside stimulation was compared with simultaneous bilateral stimulation. Average pressure reductions in small $\left(3.6 \times 3.6=13 \mathrm{~cm}^{2}\right)$ zones immediately beneath the ITs were similar for both protocols $(\sim 2.5 \mathrm{kPa}$ $(18.5 \mathrm{mmHg})$ ).

\subsection{Biomechanical considerations}

One general problem in studying PUs arises from the localized and labile nature of pressure peaks. Solis et al. described an experimental model in which they elicited DTI in rats by applying constant loads of $38 \%$ of the body weight (their expected unilateral loading in seated individuals) to the quadriceps, for 2 hours, with a $3 \mathrm{~mm}$ diameter indenter [64]. Experimental groups received intermittent NMES via nerve-cuff electrodes during this constant pressure application. In vivo assessment of deep tissue health was performed using MRI (for detecting muscle edema and oxygenation), $24 \mathrm{hrs}$ following pressure application. The authors concluded that intermittent NMES significantly reduces the amount of DTI by increasing the oxygen available to the tissue and by modifying the pressure profiles of the loaded muscles. However, because the pressure was only exerted over a very small area $\left(0.07 \mathrm{~cm}^{2}\right)$, it is likely that stimulation was in fact relieving the muscle by simply intermittently removing it from the pressure zone completely (which would not be the case with GM stimulation in seated individuals).

Solis et al. also measured the changes in GM tissue oxygenation and in surface interface pressures that resulted during GM surface stimulation in a single, able-bodied human subject. Because of limited space within the MRI scanner, muscle compression during "sitting" was simulated by adding a mass (30\% of body weight) over the pelvis of the subject, who was lying supine within the scanner with hips extended rather than flexed. A $\sim 4 \%$ reduction in tissue oxygenation (from baseline) was noted during compression of the buttocks, with a $\sim 6 \%$ increase (from baseline) after GM activation. Surface pressure profiles of the loaded muscles were redistributed and the highpressure points (over the sacrum) were reduced during surface NMES. This is consistent with the analysis of extensor moments (companion paper II, Fig. 2) [31] for this supine posture, and so the findings support a mechanism for prevention of PUs in bed-ridden patients that we have proposed previously [33]: As GM is the dominant hip extensor when the hip is extended, such as during upright locomotion and when lying in bed, the potential exists for GM stimulation to extend and abduct the hip and so roll bed-ridden patients axially, which may relieve both ischial and sacral pressures when supine.

The historical emphasis on GM may have distracted from a systematic analysis of the complete musculoskeletal mechanics. Davis \& Triolo's group recognized that the biarticular HS muscles extend the thigh at the hip, with minimal knee flexion [17], but asserted that GM is the strongest hip extensor when the hip is flexed, and that HS are optimal for hip extension when the hip and knee are extended. Older anatomy texts were referenced [29,51], and GM has been widely quoted as the strongest hip extensor without regard to hip posture. See companion paper II for a more systematic study of the biomechanics of these muscles [31]. Over the past decade Bogie \& Triolo et al. have advocated the use of GM stimulation for PU prevention [5-8, 74], but largely as part of more extensive FES involving other muscles too for standing and transfers (HS, vastus lateralis, erector spinae) [7].

While appropriately targeted NMES might reduce normal forces on soft tissues, it may actually tend to aggravate shear injury by repeated movement. Several researchers have attempted to qualify and quantify the relative importance of increased shear [24, 25, 45, 68]. Over the past decade groups such as Bouten's [10, 24, 25], Stekelenburg's [67, 68], and Linder-Ganz \& Geffen [45] have questioned one of the most basic assumptions about PU etiology: Do muscle cells under bony prominences die due to hypoxia and ischemia directly, or is tissue damage predominantly a consequence of the mechanical loading itself? Recently Linder-Ganz \& Geffen employed animal (rat) and computer models to investigate the relative effects of pressure vs. shear on capillary patency in relation to DTI [45]. Even relatively low shear strains $(<10 \%)$ were found to decrease patent capillary cross-sectional area substantially (34-55\%), so contributing to the effect of compressive stresses by increasing the extent of tissue ischemia. The effects of NMES on shear in the buttocks has not been considered in any of the studies of NMES for PU prevention to date, probably because it depends complexly on the mechanical actions of the muscles being activated, as well as the 
patient's posture, and the shape and surface texture of the seating support and clothing. The biomechanical analysis presented in companion paper II includes information about the complete skeletal moments produced by the relevant muscles [31], which would be a necessary starting point for future analysis of their effects on shear in various seating configurations.

\subsection{Interfacing technology}

In addition to questions about optimal muscle targets and pathophysiologic mechanisms, the neuralelectronic interfaces currently available for NMES are poorly suited for chronic use by these patients. To be attractive as a prophylactic measure in disabled patients who are already at risk, it is important that this activation be achieved with minimal daily intervention by the patient or caregivers, and minimal probability of side-effects or complications. Currently available technologies for NMES cannot meet all of these requirements, and include three basic platforms: (1) Surface stimulation is difficult to employ chronically because it requires precise localization of the electrodes and adjustment of stimulus parameters for each session. Repeatedly sticking large electrodes on the skin is cumbersome, and long-term practicality and patient compliance is problematic [47, 48]. Selective stimulation of the deep muscle nerves to GM and HS is difficult to achieve transcutaneously [8]. Other problems with this approach include pain and/or reflex spasms due to cutaneous stimulation, as well as pressure and irritation from the electrodes themselves, impacting skin that is often moist and already at risk for breakdown. (2) Percutaneous leads with intramuscular electrodes have been developed to improve selectivity and reliability of stimulation. However their placement is invasive, and patients run the risks of infection, erosion, fistulae, scarring, and lead breakage and migration. Repeated interventions may be required to address these issues. (3) Fully implanted multichannel stimulators with leads have also been employed, but require extensive surgery to route the leads and to place the relatively bulky stimulators (about the size of a pacemaker) [7]. These leads are also prone to infection, breakage and migration. They are probably justifiable only if they can provide functional benefits such as standing or walking.

In companion paper III [32], we present results from a clinical pilot study of a new alternative - a generic technology comprising fully implanted, minia- ture, wireless microstimulators that can be located directly at the site of stimulation.

\section{Conclusions}

NMES of the buttock muscles appears to be valuable in terms of its trophic effects, improving vascularity and soft tissue bulk. It is not clear, however, whether it can actually achieve sufficient unloading of normal forces to permit blood flow in the capillary beds of the skin and muscles. In order to prevent ischemic damage to these tissues and consequent PU formation while seated, it would seem necessary to reduce pressures (compressive stresses) periodically, in all contact areas, to below that sufficient to occlude blood flow in the capillary beds. Furthermore, this should be accomplished using muscles other than those whose blood flow is occluded while at rest. Because the weight of the body that must be supported is constant, NMES will be effective in meeting this requirement only if it produces intermittent, substantial shifts in the distribution of seating pressures between the buttocks and thighs.

\section{Acknowledgement}

This research was funded by the Alfred Mann Institute at the University of Southern California and the National Science Foundation Engineering Research Center for Biomimetic MicroElectronic Systems.

\section{References}

[1] L. Agam and A. Gefen, Toward real-time detection of deep tissue injury risk in wheelchair users using Hertz contact theory, J Rehabil Res Dev 45(4) (2008), 537-550.

[2] V. Allen, D.W. Ryan and A. Murray, Air-fluidized beds and their ability to distribute interface pressures generated between the subject and the bed surface, Physiol Meas 14(3) (Aug 1993), 359-364.

[3] M.A. Ankrom, R.G. Bennett, S. Sprigle, D. Langemo, J.M. Black, D.R. Berlowitz and C.H. Lyder, National Pressure Ulcer Advisory Panel, Pressure-related deep tissue injury under intact skin and the current pressure ulcer staging systems, Adv Skin Wound Care 18 (Jan-Feb 2005), 35-42.

[4] J. Black, M. Baharestani, J. Cuddigan, B. Dorner, L. Edsberg, D. Langemo, M.E. Posthauer, C. Ratliff and G. Taler, National Pressure Ulcer Advisory Panel's updated pressure ulcer staging system, Urol Nurs 27(2) (2007), 144-150. 
[5] K.M. Bogie, S.I. Reger, S.P. Levine and V. Sahgal, Electrical stimulation for pressure sore prevention and wound healing, Asst Technol 12 (2000), 50-66.

[6] K.M. Bogie, R.J. Triolo and J. Chae, Improving the health of paralyzed tissue using electrical stimulation, Proc 3rd Conf Rehab Res Dev, US Dept of Veterans Affairs, Feb 2002

[7] K.M. Bogie and R.J. Triolo, Effects of regular use of neuromuscular electrical stimulation on tissue health, J Rehab Res Dev 40(6) (Nov-Dec 2003), 469-476.

[8] K.M. Bogie, X. Wang and R.J. Triolo, Long-term prevention of pressure ulcers in high-risk patients: a single case study of the use of gluteal neuromuscular electric stimulation, Arch Phys Med Rehabil 87 (Apr 2006), 585-591.

[9] C. Bouten, C. Oomens, D. Colin and D. Bader, The aetiopathology of pressure ulcers: a hierarchical approach, In: Pressure Ulcer Research: Current and Future Perspectives, D. Bader, C. Bouten, D. Colin C. Oomens, eds, SpringerVerlag, Berlin, 2005, p. 3.

[10] C.V. Bouten, M.M. Knight, D.A. Lee and D.L. Bader, Compressive deformation and damage of muscle cell subpopulations in a model system, Ann Biomed Eng 29(2) (Feb 2001), 153-163.

[11] C.V. Bouten, C.W. Oomens, F.P. Baaijens and D.L. Bader, The etiology of pressure ulcers: Skin deep or muscle bound, Arch Phys Med Rehab 84(4) (Apr 2003), 616-619.

[12] G.H. Brandeis, J.N. Morris, D.J. Nash and L.A. Lipsitz, The epidemiology and natural history of pressure ulcers in elderly nursing home residents, JAMA 264(22) (Dec 1990), 2905-2909.

[13] R.G. Breuls, C.V. Bouten, C.W. Oomens, D.L. Bader and F.P. Baaijens, A theoretical analysis of damage evolution in skeletal muscle tissue with reference to pressure ulcer development, J Biomech Eng 125(6) (Dec 2003), 902-909.

[14] R.G. Breuls, B.G. Sengers, C.W. Oomens, C.V. Bouten and F.P. Baaijens, Predicting local cell deformations in engineered tissue constructs: A multilevel finite element approach, $J$ Biomech Eng 124(2) (Apr 2002), 198-207.

[15] O.K. Coşkunfirat and H.E. Ozgentaş, Gluteal perforator flaps for coverage of pressure sores at various locations, Plast Reconstr Surg 113(7) (Jun 2004), 2012-2017.

[16] R.K. Daniel, D.L. Priest and D.C. Wheatley, Etiologic factors in pressure sores: An experimental model, Arch Phys Med Rehabil 62(10) (Oct 1981), 492-498.

[17] J.A. Davis, R.J. Triolo, J.P. Uhlir, N. Bhadra, D.A. Lissy, S. Nandurkar and E.B. Marsolais, Surgical technique for installing an eight-channel neuroprosthesis for standing, Clin Orthop Relat $R 385$ (Apr 2001), 237-252.

[18] J.S. Davis, Operative treatment of scars following bed sores, Surgery 3(1) (1938).

[19] J.J. Disa, J.M. Carlton and N.H. Goldberg, Efficacy of operative cure in pressure sore patients, Plast Reconstr Surg 89(2) (Feb 1992), 272-278.

[20] G.R.D. Evans, C.R. Dufresne and P.N. Manson, Surgical correction of pressure ulcers in an urban center: Is it efficacious, Adv Wound Care 7 (1994), 40-46.

[21] A.C. Ferguson, J.F. Keating, M.A. Delargy and B.J. Andrews, Reduction of seating pressure using FES in patients with spinal cord injury, A preliminary report, Paraplegia 30(7) (Jul 1992), 474-478.

[22] R.D. Foster, J.P. Anthony, S.J. Mathes and W.Y. Hoffman, Ischial pressure sore coverage: A rationale for flap selection, Br J Plast Surg 50(5) (Jul 1997), 374-379.
[23] M. Fuhrer, S.L. Garber, DH. Rintala, R. Clearman and K.A. Hart, Pressure ulcers in community-resident persons with spinal cord injury: Prevalence and risk factors, Arch Phys Med Rehab 74(11) (Nov 1993), 1172-1177.

[24] D. Gawlitta, W. Li, C.W. Oomens, F.P. Baaijens, D.L. Bader and C.V. Bouten, The relative contributions of compression and hypoxia to development of muscle tissue damage: An in vitro study, Ann Biomed Eng 35 (Epub Nov 29, 2006. Feb 2007a), 273-284.

[25] D. Gawlitta, C.W. Oomens, D.L. Bader, F.P. Baaijens and C.V. Bouten, Temporal differences in the influence of ischemic factors and deformation on the metabolism of engineered skeletal muscle, J Appl Physiol 103(2) (Epub Apr 19, 2007. Aug 2007b), 464-473.

[26] A. Gefen, N. Gefen, E. Linder-Ganz and S.S. Margulies, In vivo muscle stiffening under bone compression promotes deep pressure sores, J Biomech Eng 127(3) (Jun 2005), 512-524.

[27] R. Ger, The surgical management of decubitus ulcers by muscle transposition, Surgery 69(1) (1971), 106-110.

[28] C.H. Ho and K. Bogie, The prevention and treatment of pressure ulcers, Phys Med Rehabil Clin N Am 18(2) (May 2007), 235-253.

[29] W.H. Hollinshead and D.B. Jenkins Functional Anatomy of the Limbs and Back, 5th Ed., WB Saunders, Philadelphia, PA, 1981, pp. 262-275.

[30] T.W.J. Janssen, A. van Londen, M. Herwegh, C.H. van der Zee, C.A.J. Smit, A. Niezen and A. Daffertshofer, Surface electrical stimulation of gluteal muscles reduces sitting pressure in wheelchair users with a spinal cord injury, Proc 12th International Functional Electrical Stimulation Soc, Philadelphia, PA, Nov 2007.

[31] H.M. Kaplan, L.L. Baker, R. Davoodi, N.T. Wong and G.E. Loeb, Preventing ischial pressure ulcers: II. Biomechanics Companion Paper. 2011a.

[32] H.M. Kaplan, L.L. Baker, S. Rubayi and G.E. Loeb, Preventing ischial pressure ulcers: III. Clinical pilot study of chronic neuromuscular electrical stimulation, Companion Paper, 2011b.

[33] H.M. Kaplan, G.E. Loeb, Method and apparatus for pressure ulcer prevention and treatment. USPTO Patent Application 60/977,437. Assignee: Alfred Mann Institute for Biomedical Engineering at the University of Southern California, Los Angeles, CA. Filed, Oct 2007.

[34] K.A. Keys, L. Daniali, K.J. Warner and D.W. Mathes, Multivariate predictors of pressure ulcer recurrence, J Am Coll Surg 209(3, Suppl 1), (Sep 2009), S79.

[35] P.C. Kierney, L.H. Engrav, F.F. Isik, P.C. Esselman, D.D. Cardenas and R.P. Rand, Results of 268 pressure sores in 158 patients managed jointly by plastic surgery and rehabilitation medicine, Plast Reconstr Surg 102(3) (Sep 1998), 765772.

[36] W.M. Klein, L.W. Bartels, L. Bax, Y. van der Graaf and W.P.T.M. Mali, Magnetic resonance imaging measurement of blood volume flow in peripheral arteries in healthy subjects, $J$ Vasc Surg 38(5) (Nov 2003), 1060-1066.

[37] M. Kosiak, Etiology of decubitus ulcers, Arch Phys Med Rehabil 42 (Jan 1961), 19-29.

[38] M. Kuwahara, H. Tada, K. Mashiba, S. Yurugi, H. Iioka, K. Niitsuma and Y. Yasuda, Mortality and recurrence rate after pressure ulcer operation for elderly long-term bedridden patients, Ann Plast Surg 54(6) (Jun 2005), 629-632. 
[39] B. Leblebici, N. Turhan, M. Adam and M.N. Akman, Clinical and epidemiologic evaluation of pressure ulcers in patients at a university hospital in Turkey, $J$ Wound Ostomy Continence Nurs 34 (Jul-Aug 2007), 407-411.

[40] S.S. Lee, S.H. Huang, M.C. Chen, K.P. Chang, C.S. Lai and S.D. Lin, Management of recurrent ischial pressure sore with gracilis muscle flap and V-Y profunda femoris artery perforator-based flap, J Plast Reconstr Aesthet Surg 62(10) (Epub Jul 2, 2008. Oct 2009), 1339-1346.

[41] S.P. Levine, Functional electrical stimulation for pressure sore inhibition. USPTO Patent 4,727,878. Assignee: University of Michigan, Ann Arbor, MI. Filed: Sep 1985. Issued: Mar 1988.

[42] S.P. Levine, R.L. Kett, B.S. Cederna, L.D. Bowers and S.V. Brooks, Electrical muscle stimulation for pressure variation at the seating interface, J Rehab Res Dev 26(4) (1989), 1-7.

[43] S.P. Levine, R.L. Kett, P.S. Cederna and S.V. Brooks, Electric muscle stimulation for pressure sore prevention: tissue shape variation, Arch Phys Med Rehabil 71(3) (Mar 1990a), 210-215.

[44] S.P. Levine, R.L. Kett, M.D. Gross, B.A. Wilson, P.S. Cederna and J.E. Juni, Blood flow in the gluteus maximus of seated individuals during electrical muscle stimulation, Arch Phys Med Rehabil 71(9) (Aug 1990b), 682-686.

[45] E. Linder-Ganz and A. Geffen, The effects of pressure and shear on capillary closure in the microstructure of skeletal muscles, Ann Biomed Eng 35(12) (Dec 2007), 2095-2107.

[46] J.R. Linderman and M.A. Boegehold, Arteriolar network growth in rat striated muscle during juvenile maturation, Int J Microcirc Clin Exp 16(5) (Sep-Oct 1996), 232-239.

[47] L.Q. Liu, G.P. Nicholson, S.L. Knight, R. Chelvarajah, A. Gall, F.R. Middleton, M.W. Ferguson-Pell and M.D. Craggs, Pressure changes under the ischial tuberosities of seated individuals during sacral nerve root stimulation, J Rehabil Res Dev 43(2) (Mar-Apr 2006a), 209-218.

[48] L.Q. Liu, G.P. Nicholson, S.L. Knight, R. Chelvarajah, A. Gall, F.R.I. Middleton, M.W. Ferguson-Pell and M.D. Craggs, Interface pressure and cutaneous hemoglobin and oxygenation changes under ischial tuberosities during sacral nerve root stimulation in spinal cord injury, J Rehabil Res Dev 43(4) (Jul-Aug 2006b), 553-564.

[49] A. Margara, G. Merlino, M. Borsetti, F. Bergamin and G. Borsetti, A proposed protocol for the surgical treatment of pressure sores based on a study of 337 cases, Eur J Plast Surg 26 (2003), 57-61

[50] J.B. McGraw and P.G. Arnold, McGraw and Arnold's Atlas of Muscle and Musculocutaneous Flaps, Norfolk, VA: Hampton Press (1986).

[51] C. McVay, Surgical Anatomy, Vol II, WB Saunders, Philadelphia, PA, 1984.

[52] K.L. Moore and A.F. Dalley, Clinically Oriented Anatomy, 5th Ed. Lippincott Williams \& Wilkins, Philadelphia, PA, 2005, 591-596.

[53] National Decubitus Foundation, Cost Savings Through Bedsore Avoidance, National Decubitus Foundation, Aurora, CO, 2004.

[54] National Pressure Ulcer Advisory Panel Pressure Ulcers in America, Prevalence, Incidence, and Implications for the Future: Executive Summary of the National Pressure Ulcer Advisory Panel Monograph. Cuddigan, J, Berlowitz, DR, Ayello, EA, section editors. Adv Skin Wound Care 14(4,1/2) (Jul-Aug 2001), 208-215.
[55] National Pressure Ulcer Advisory Panel, Updated Pressure Ulcer Staging System 2007, National Pressure Ulcer Advisory Panel, Washington, DC, Feb 2007.

[56] National Spinal Cord Injury Statistical Center, Annual Report for the Model Spinal Cord Injury Care Systems, University of Alabama, Birmingham, AL, 2006, pp. 119121.

[57] National Spinal Cord Injury Statistical Center, Spinal Cord Injury Facts and Figures at a Glance, University of Alabama, Birmingham, AL, Feb 2010.

[58] J.L. Olive, G.A. Dudley and K.K. McCully, Vascular remodeling after spinal cord injury, Med Sci Sports Exerc 35(6) (Jun 2003), 901-907.

[59] G. Rådegran, E. Blomstrand and B. Saltin, Peak muscle perfusion and oxygen uptake in humans: importance of precise estimates of muscle mass, $J$ Appl Physiol 87(6) (Dec 1999), 2375-2380.

[60] J.B. Reswick and J.E. Rogers, Experience at Rancho Los Amigos hospital with devices and techniques to prevent pressure sores, In: R.M. Kenedi, J.M. Cowden J.T. Scales (Eds), Bedsore Biomechanics, University Park Press, Baltimore, MD, 1976, pp. 301-310.

[61] O.I. Schryvers, M.F. Stranc and P.W. Nance, Surgical treatment of pressure ulcers: 20-year experience, Arch Phys Med Rehab 81 (Dec 2000), 1556-1562.

[62] J.D. Shea, Pressure sores: classification and management, Clin Orthop Relat Res 112 (Oct 1975), 89-100.

[63] S.A. Sisto, G.F. Forrest and P.D. Faghri, Technology for mobility and quality of life in spinal cord injury, IEEE Eng Med Biol Mag 27(2) (Mar-Apr 2008), 56-68.

[64] L.R. Solis, D.P. Hallihan, R.R.E. Uwiera, R.B. Thompson, E.D. Pehowich and V.K. Mushahwar, Prevention of pressure-induced deep tissue injury using intermittent electrical stimulation, J Appl Physiol 102 (Feb 2007), 1992-2001.

[65] J.L. Sørensen, B. Jørgensen and F. Gottrup, Surgical treatment of pressure ulcers, Am J Surg 188(1A Suppl) (Jul 2004), 42-51.

[66] A. Stekelenburg, D. Gawlitta, D.L. Bader and C.W. Oomens, Deep tissue injury: how deep is our understanding, Arch Phys Med Rehabil 89(7) (Jul 2008), 1410-1413.

[67] A. Stekelenburg, C.W. Oomens, G.J. Strijkers, K. Nicolay and D.L. Bader, Compression-induced deep tissue injury examined with magnetic resonance imaging and histology, J Appl Physiol 100(6) (Epub Feb 16, 2006. Jun 2006), 19461954.

[68] A. Stekelenburg, G.J. Strijkers, H. Parusel, D.L. Bader, K. Nicolay and C.W. Oomens, Role of ischemia and deformation in the onset of compression-induced deep tissue injury: MRIbased studies in a rat model, J Appl Physiol 102 (Epub Jan 25, 2007. May 2007), 2002-2011.

[69] K. Tavakoli, S. Rutkowski, C. Cope, M. Hassall, R. Barnett, M. Richards and J. Vandervord, Recurrence rates of ischia sores in para- and tetraplegics treated with hamstring flaps: an 8-year study, Br J Plast Surg 52(6) (1999), 476-479.

[70] D.R. Thomas, Prevention and treatment of pressure ulcers: What works? What doesn't? Cleve Clin J Med, 68(8) (Aug 2001), 704-7 710-14 717-22.

[71] UAB Model SCI System, Spinal Cord Injury Info Sheet \#13: Prevention of Pressure Ulcers through Skin Care, Estill, S, ed., University of Alabama, Birmingham, AL, Oct 2007, pp. 2-3. 
[72] A. van Londen, M. Herwegh, C.H. van der Zee, A. Daffertshofer, C.A. Smit, A. Niezen and T.W. Janssen, The effect of surface electric stimulation of the gluteal muscles on the interface pressure in seated people with spinal cord injury, Arch Phys Med Rehabil 89(9) (Sep 2008), 1724-1732.

[73] B.J. Wilhelmi and M. Neumeister, Pressure ulcers, surgical treatment and principles, Emedicine Aug 2008. Available at: http://emedicine.medscape.com/article/1293614-print. Accessed Nov 2, 2009

[74] G.A. Wu and K. Bogie, Assessment of gluteus maximus muscle area with different image analysis programs, Arch Phys Med Rehabil 90(6) (Jun 2009), 1048-1054.

[75] G.M. Yarkony, Pressure ulcers: a reviewArch Phys Med Rehabil, Arch Phys Med Rehabil 75(8) (Aug 1994), 908-917. 

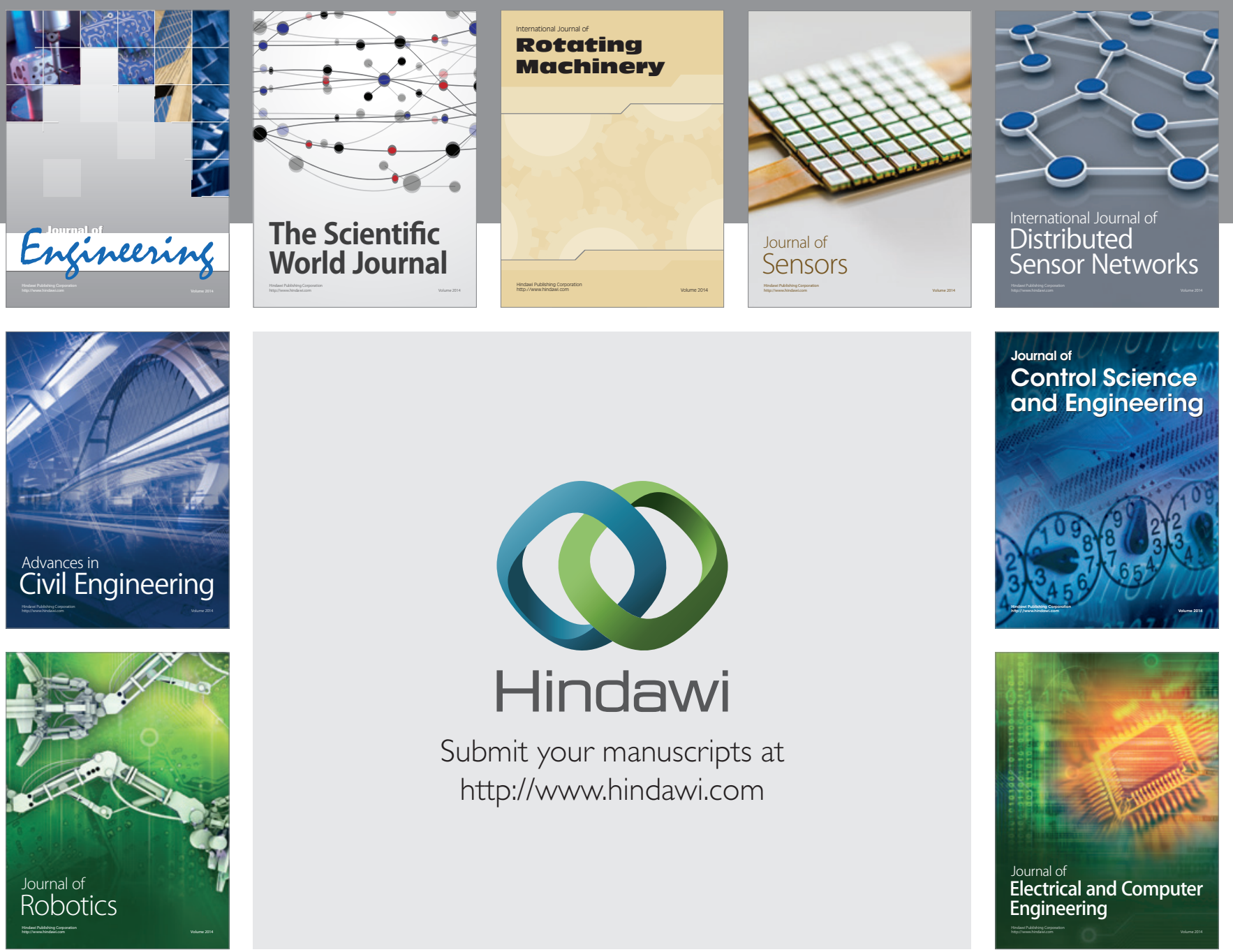

Submit your manuscripts at

http://www.hindawi.com
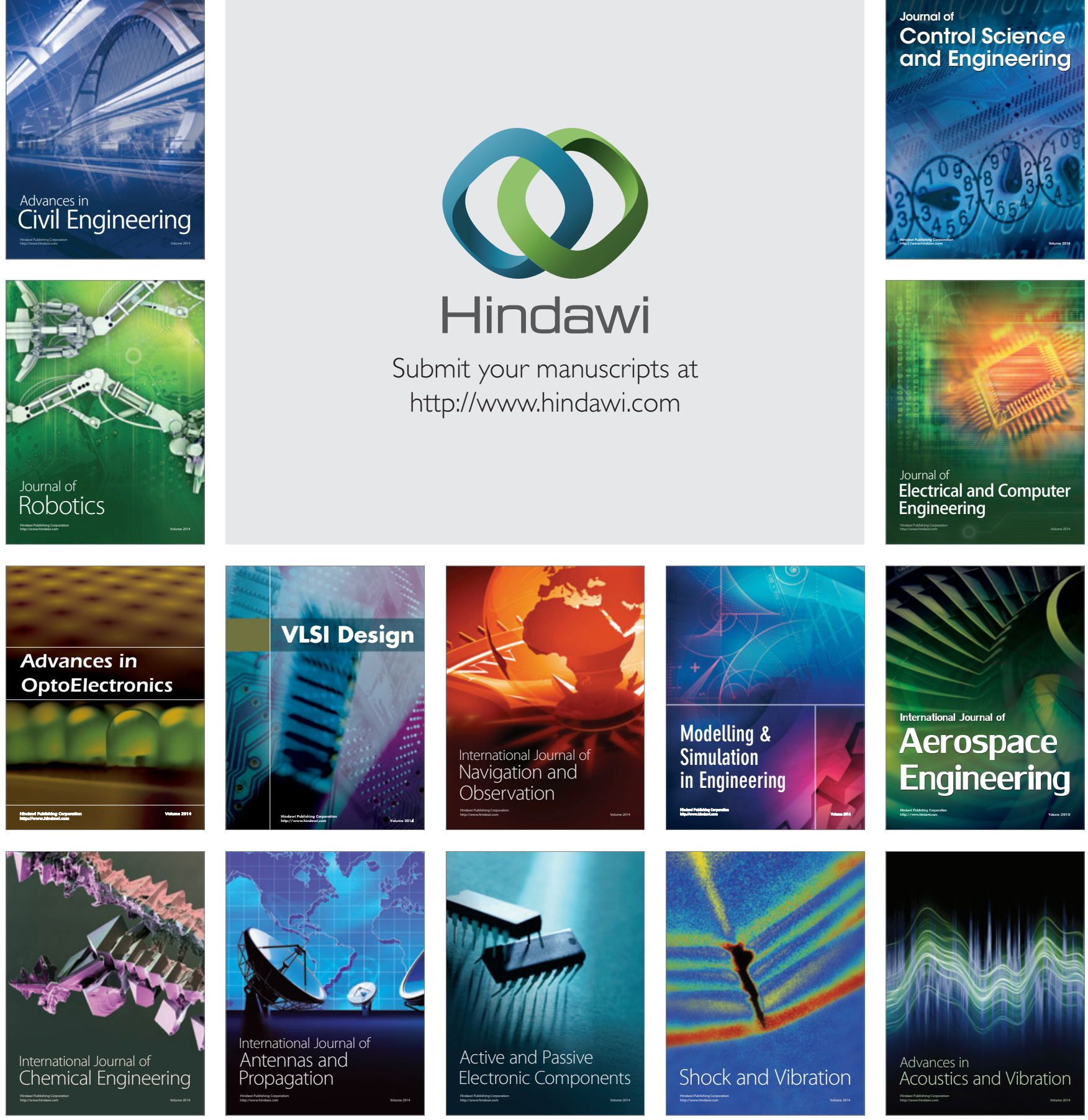